\title{
SYNTHESIS AND CHARACTERIZATION OF Cu(II) COMPLEXES OF PROTON TRANSFER SALTS DERIVED FROM PIPERAZINE DERIVATIVES AND 5-SULFOSALICYLIC ACID
}

\author{
Nurgün Büyükkıdan ${ }^{1}$, Halil İlkimen ${ }^{1}$, Büşra Durmuş ${ }^{1}$, Aysel Gülbandılar ${ }^{2}$ \\ ${ }^{1}$ Chemistry Department, Arts and Sciences Faculty, Kütahya Dumlupinar University, \\ 43100 Kütahya, Turkey \\ ${ }^{2}$ Department of Food Engineering, Department of Agricultural Engineering, \\ Eskişehir Osmangazi University, 26000 Eskişehir, Turkey \\ nurgun.buyukkidan@dpu.edu.tr
}

\begin{abstract}
In this study, proton transfer salts $\left(\mathrm{H}_{2}\right.$ Etpip)(Hssa), $\left(\mathrm{H}_{2} \mathrm{HOEtpip}\right)(\mathrm{Hssa})$ and (HAcpip) $\left(\mathrm{H}_{2} \mathrm{ssa}\right)$, have been obtained by reactions between 1-ethylpiperazine (Etpip), 1-(2-hydroxyethyl)piperazine (HOEtpip) and 1-acetylpiperazine (Acpip) and 5-sulfosalicylic acid $\left(\mathrm{H}_{3}\right.$ ssa). Also, $\mathrm{Cu}(\mathrm{II})$ complexes of proton transfer salts $\left(\mathrm{H}_{2} \mathrm{Etpip}\right)\left[\mathrm{Cu}(\mathrm{Hssa})_{2}\right] \cdot 5 \mathrm{H}_{2} \mathrm{O},\left(\mathrm{H}_{2} \mathrm{HOEtpip}\right)\left[\mathrm{Cu}(\mathrm{Hssa})_{2}\right] \cdot 5 \mathrm{H}_{2} \mathrm{O}$ and $\left.\left(\mathrm{H}_{2} \mathrm{Acpip}\right)\left[\mathrm{Cu}(\mathrm{Hssa})_{2}\right] \cdot 5 \mathrm{H}_{2} \mathrm{O}\right)$ have been synthesized. The structures of proton transfer salts have been proposed by using FT-IR, ${ }^{1} \mathrm{H}$ and ${ }^{13} \mathrm{C}$ NMR spectroscopy, and elemental analysis. The structures of the amorphous metal complexes have been proposed by atomic absorption spectrometry, FT-IR, magnetic susceptibility, molar conductivity techniques, and elemental analysis. Antimicrobial activities of compounds have been tested against Staphylococcus aureus (ATCC 29213) (Gram-positive), Escherichia coli (ATCC 25922) (Gram-negative), Candida krusei (ATCC 6258) (yeast), and Candida parapsilosis (ATCC 22019) (yeast) microorganisms. For S. aureus, the minimum inhibitory concentration (MIC) values of the synthesized salts were between 31.25 and $62.50 \mu \mathrm{g} / \mathrm{ml}$, and $15.60 \mu \mathrm{g} / \mathrm{ml}$ for complexes. The MIC values of salts and complexes for $E$. coli were in the range $125.00-500.00 \mu \mathrm{g} / \mathrm{ml}$ and $31.25-62.50 \mu \mathrm{g} / \mathrm{ml}$, respectively. The MIC values of the salts for $C$. krusei were $62.50 \mu \mathrm{g} / \mathrm{ml}$, and for the complexes in the range 15.60-31.25 $\mu \mathrm{g} / \mathrm{ml}$. For C. parapsilosis, these values were $31.25 \mu \mathrm{g} / \mathrm{ml}$ for all salts and in the range $15.60-62.50 \mu \mathrm{g} / \mathrm{ml}$ for complexes.
\end{abstract}

Keywords: 5-sulfosalicylic acid; 1-piperazine derivatives; proton transfer salt; metal complexes; antimicrobial activity

\section{СИНТЕЗА И КАРАКТЕРИЗАЦИЈА НА СИ(ІІ)-КОМПЛЕКСИ НА СОЛИТЕ ПРЕНОСИТЕЛИ НА ПРОТОН ДОБИЕНИ ОД ПИПЕРАЗИНСКИ ДЕРИВАТИ НА 5-СУЛФОСАЛИЦИЛНА КИСЕЛИНА}

Во оваа студија се добиени соли за пренос на протон трансфер ( $\mathrm{H}_{2}$ Etpip)(Hssa), $\left(\mathrm{H}_{2} \mathrm{HOEtpip}\right)(\mathrm{Hssa})$ и (HAcpip) $\left(\mathrm{H}_{2} \mathrm{ssa}\right)$ при реакција на 1-етилпиперазин (Etpip), 1-(2хидроксиетил)пиперазин (НОЕtрір) и 1-ацетилпиперазин (Асрір) со 5-сулфосалицилна киселина $\left(\mathrm{H}_{3} \mathrm{ssa}\right)$. Покрај тоа беа синтетизирани и $\mathrm{Cu}(\mathrm{II})$-комплекси на соли за пренос на протон $\left(\mathrm{H}_{2} \mathrm{Etpip}\right)\left[\mathrm{Cu}(\mathrm{Hssa})_{2}\right] \cdot 5 \mathrm{H}_{2} \mathrm{O}$, ( $\left.\mathrm{H}_{2} \mathrm{HOEtpip}\right)\left[\mathrm{Cu}(\mathrm{Hssa})_{2}\right] \cdot 5 \mathrm{H}_{2} \mathrm{O}$ и $\left.\left(\mathrm{H}_{2} \mathrm{Acpip}\right)\left[\mathrm{Cu}(\mathrm{Hssa})_{2}\right] \cdot 5 \mathrm{H}_{2} \mathrm{O}\right)$. Структурите на солите за пренос на протон се предложени врз основа на FT-IR, на ${ }^{1} \mathrm{H}$ и ${ }^{13} \mathrm{C}$ NMR спектроскопија и на елементна анализа. Структурите на аморфните и метални комплекси се предложени врз основа на атомска апсорпциона спектрометрија, FT-IR, магнетен сусцептибилитет, техники на моларна спроводливост и елементна анализа. Антимикорбните активности на соединенијата беа тестирани со микроорганизми на Staphylococcus aureus (ATCC 29213) (Грампозитивни), Escherichia coli (АТCC 25922) (Грам-негативни), Candida krusei (АTCC 6258) (квасец) и Candida parapsilosis (ATCC 22019) (квасец). За S. aureus вредностите на минималната инхибиторна концентрација (МIC) на синтетизираните соли беа меѓу 31,25 и $62,50 \mu \mathrm{g} / \mathrm{ml}$, и $15,60 \mu \mathrm{g} / \mathrm{ml}$ за комплексите. Вредностите на МIC солите и на комплексите за E. coli беа во опсег од 125,00 до

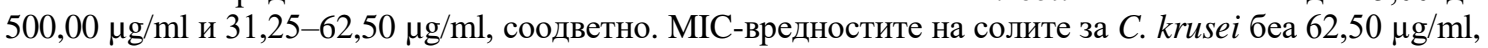


додека за комплексите беа во опсегот од 15,60 до $31,25 \mu \mathrm{g} / \mathrm{ml}$. За C. parapsilosis овие вредности изнесуваа $31,25 \mu \mathrm{g} / \mathrm{ml}$ за сите соли, а за комплексите од $15,60-62,50 \mu \mathrm{g} / \mathrm{ml}$.

Клучни зборови: 5-сулфосалицилна киселина; 1-пиперазин деривати; соли за пренос на протон; комплекси на метали; антимикробна активност

\section{INTRODUCTION}

Among the aromatic sulfonic acids, 5sulfosalicylic acid is especially important because it has three functional groups: $-\mathrm{OH},-\mathrm{COOH}$, and $-\mathrm{SO}_{3} \mathrm{H}$. These groups react with organic bases (aliphatic and aromatic amines and heterocyclic Ncontaining compounds) to form supramolecular sequences through strong hydrogen bonding interactions [1-3]. 5-Sulfosalicylic acid acts as a multichelated ligand in complex formation. It contains a sulfonyl group $\left(-\mathrm{SO}_{3} \mathrm{H}\right)$, a carboxyl group $(-\mathrm{COOH})$ and a phenolic group $(-\mathrm{OH})$ and has a total of six donor sites for coordination with the metal. Crystallographic examinations of the complexes of 5-sulfosalicylic acid containing alkali, alkaline earth and main-group metals show that the structures of these compounds are substantially polymeric [4-14]. Complexes containing mixed metals have also been found $[5,15,16]$. Furthermore, the 5-sulfosalicylate anion can be present as a complementary ion without coordination to a metal [17]. Many complexes have been reported in which the central metal atom coordinates to one [5, 10], two [18], three [5] or four [10, 19, 20] 5sulfosalicylate anions. Although 5-sulfosalicylic acid is known to have biological activity, metal complexes have been found to exhibit more antimicrobial activity than free 5-sulfosalicylic acid $[21,22]$. The chemistry of $\mathrm{Cu}$ (II) carboxylate complexes with ligands containing an $\mathrm{N}$-donor has been extensively studied [23-26]. The $\mathrm{Cu}(\mathrm{II}) \mathrm{com}-$ plex of 5-sulfosalicylate and 2,2'-bipyridine features a charge-transfer type with two cationic and anionic chains in which both carboxyl and sulfonyl are coordinated to $\mathrm{Cu}$ atoms [27]. Copper complexes of substituted benzothiazole and 5sulfosalicylic acid have been synthesized and their anti-inflammatory and analgesic activities investigated [28]. Piperazine can coordinate through one or two $\mathrm{N}$ atoms to the metal as well as bonding to metal centers as a bridging ligand. The metal complexes of proton transfer salts, including piperazine, and some mono- and dicarboxylic acids, have been reported [29-31]. In the $\mathrm{Cu}$ (II) complex of the proton transfer salt of pyridine-2,6-dicarboxylic acid and 2-(piperazin-1-yl)ethanol it is present only as a complementary ion in the structure [32]. Studies have shown that piperazine and its derivatives have many biological activities [33-36].
In this study, the proton transfer compounds 1-3 and $\mathrm{Cu}(\mathrm{II})$ complexes 4-6 have been synthesized. The structures of the proton transfer salts 13 were determined by elemental and spectral (FT$\mathrm{IR},{ }^{1} \mathrm{H}$ and ${ }^{13} \mathrm{C} \mathrm{NMR}$ ) analyses. Elemental analysis, atomic absorption spectrometry (AAS), FT-IR, magnetic susceptibility and molar conductivity techniques have been used to elucidate proposed structures of the amorphous metal complexes 4-6. We have studied the antimicrobial activities of 16, $\mathrm{H}_{3}$ ssa, Etpip, HOEtpip, Acpip on the growth of Staphylococcus aureus, Escherichia coli, Candida krusei, and Candida parapsilosis cultures.

\section{EXPERIMENTAL}

\subsection{Materials and methods}

The chemicals used in this study were obtained from Sigma Aldrich and used without further purification.

Elemental analysis was carried out by Thermo Finnigan Flash model EA 1112 elemental analyzer. AAS studies were carried out using Perkin Elmer model PinAAcle 900T. ${ }^{1} \mathrm{H}$ and ${ }^{13} \mathrm{C}$ NMR spectra of the synthesized compounds were recorded in DMSO using a $500 \mathrm{MHz}$ UltraShield NMR spectrometer. FT-IR studies were carried out using a Bruker Optics Vertex 70 instrument using ATR. A Sherwood Scientific Magway MSB MK1 instrument was used for magnetic susceptibility studies. Molar conductivity measurements were performed using a WTW Cond model 315i/ ET instrument using $10^{-3} \mathrm{M}$ solutions in DMSO.

\subsection{General procedure for synthesis of proton transfer salts 1-3}

In a 1:1 ratio, 5-sulfosalicylic acid $(2.18 \mathrm{~g}$, $10.0 \mathrm{mmol}$ ) was dissolved in $15 \mathrm{ml}$ of pure ethanol and added dropwise to $15 \mathrm{ml}$ of base solution (Etpip, HOEtpip and Acpip) dissolved in ethanol. The white proton transfer salts $\left(\mathrm{H}_{2}\right.$ Etpip)(Hssa) (1), $\left(\mathrm{H}_{2} \mathrm{HOEtpip}\right)$ (Hssa) (2) and $\left(\mathrm{H}_{2} \mathrm{Acpip}\right)(\mathrm{Hssa})$ (3) were obtained by stirring the reaction mixture at room temperature for $24 \mathrm{~h}$. The white solids were filtered, washed with ethanol, and dried. The physical properties of proton transfer salts 1-3 are given in Table 1. 


\subsection{General procedure for synthesis of metal complexes 4-6}

The proton transfer salt $(\mathbf{1}-\mathbf{3})(1 \mathrm{mmol})$ was dissolved in $10 \mathrm{ml}$ of water/ethanol (1:1). An aqueous solution $(10 \mathrm{ml})$ of $\mathrm{Cu}\left(\mathrm{CH}_{3} \mathrm{COO}\right)_{2} \cdot \mathrm{H}_{2} \mathrm{O}(1 \mathrm{mmol}$, $0.200 \mathrm{~g}$ ) was added to the proton transfer salt $(\mathbf{1}-\mathbf{3})$ solution and the reaction mixture stirred at room temperature for $72 \mathrm{~h}$. The resulting amorphous $\mathrm{Cu}(\mathrm{II})$ metal complexes $\left(\mathrm{H}_{2} \mathrm{Etpip}\right)\left[\mathrm{Cu}\left(\mathrm{Hssa}_{2}\right)_{2} \cdot 5 \mathrm{H}_{2} \mathrm{O}\right.$ (4), $\left(\mathrm{H}_{2} \mathrm{HOEtpip}\right)\left[\mathrm{Cu}(\mathrm{Hssa})_{2}\right] \cdot 5 \mathrm{H}_{2} \mathrm{O}$ (5) and $\left(\mathrm{H}_{2} \mathrm{Acpip}\right)$ $\left[\mathrm{Cu}(\mathrm{Hssa})_{2}\right] \cdot 5 \mathrm{H}_{2} \mathrm{O}(\mathbf{6})$ were filtered and dried in air. The physical properties of complexes 4-6 are given in Table 1.

Table 1

The physical properties of salts 1-3 and metal complexes 4-6

\begin{tabular}{cccccc}
\hline \hline Compound & Closed formula & MW $^{*}(\mathbf{g} / \mathbf{m o l})$ & Color & Yield (\%) & m.p. $\left({ }^{\circ} \mathbf{C}\right)$ \\
\hline $\mathbf{1}$ & $\mathrm{C}_{13} \mathrm{H}_{20} \mathrm{~N}_{2} \mathrm{O}_{6} \mathrm{~S}$ & 332.32 & White & 85 & 249.5 \\
$\mathbf{2}$ & $\mathrm{C}_{13} \mathrm{H}_{20} \mathrm{~N}_{2} \mathrm{O}_{7} \mathrm{~S}$ & 348.37 & White & 90 & 218.8 \\
$\mathbf{3}$ & $\mathrm{C}_{13} \mathrm{H}_{18} \mathrm{~N}_{2} \mathrm{O}_{7} \mathrm{~S}$ & 346.36 & White & 85 & 245.0 \\
$\mathbf{4}$ & $\mathrm{C}_{20} \mathrm{H}_{34} \mathrm{CuN}_{2} \mathrm{O}_{17} \mathrm{~S}_{2}$ & 702.16 & Green & 65 & 280.5 \\
$\mathbf{5}$ & $\mathrm{C}_{20} \mathrm{H}_{34} \mathrm{CuN}_{2} \mathrm{O}_{18} \mathrm{~S}_{2}$ & 718.16 & Green & 70 & 227.8 \\
$\mathbf{6}$ & $\mathrm{C}_{20} \mathrm{H}_{32} \mathrm{CuN}_{2} \mathrm{O}_{18} \mathrm{~S}_{2}$ & 716.15 & Green & 65 & 295.7 \\
\hline \hline
\end{tabular}

*Estimated MW

Analysis. Calcd. for $1\left(\mathrm{C}_{13} \mathrm{H}_{20} \mathrm{~N}_{2} \mathrm{O}_{6} \mathrm{~S}\right)$ : C, $47.00 \%$; H, $6.10 \%$; N $8.40 \%$; S, $9.65 \%$. Found: C, $46.98 \%$; H, $6.07 \%$; N, $8.43 \%$; S, $9.65 \%$. Calcd. for $2\left(\mathrm{C}_{13} \mathrm{H}_{20} \mathrm{~N}_{2} \mathrm{O}_{7} \mathrm{~S}\right): \mathrm{C}, 44.81 \% ; \mathrm{H}, 5.75 \% ; \mathrm{N}, 8.02 \%$; S, $9.27 \%$. Found: C, $44.82 \%$; H, $5.79 \%$; N, $8.04 \%$; S, $9.20 \%$. Calcd. for $3\left(\mathrm{C}_{13} \mathrm{H}_{18} \mathrm{~N}_{2} \mathrm{O}_{7} \mathrm{~S}\right)$ : C, $45.08 \%$; $\mathrm{H}, 5.25 \%$; N, $8.10 \%$; S, $9.23 \%$. Found: C, $45.08 \%$; $\mathrm{H}, 5.24 \%$; N, $8.09 \%$; S, $9.26 \%$. Calcd. for 4 $\left(\mathrm{C}_{20} \mathrm{H}_{34} \mathrm{CuN}_{2} \mathrm{O}_{17} \mathrm{~S}_{2}\right): \mathrm{C}, 34.21 \% ; \mathrm{H}, 4.88 \% ; \mathrm{N}, 3.99$ $\%$; S, $9.13 \%$; Cu $9.05 \%$. Found: C, $34.20 \%$; 4.90; N, $4.00 \% ; \mathrm{S}, 9.10 \%$; Cu, $9.05 \%$. Calcd. for 5 $\left(\mathrm{C}_{20} \mathrm{H}_{34} \mathrm{CuN}_{2} \mathrm{O}_{18} \mathrm{~S}_{2}\right): \mathrm{C}, 33.45 \% ; \mathrm{H}, 4.77 \% ; \mathrm{N}, 3.90$ $\%$; S, $8.93 \%$; Cu, $8.85 \%$. Found: C, $33.45 \%$; $4.75 \%$; N, $3.91 \% ; \mathrm{S}, 8.95 \%$; Cu, $8.87 \%$. Calcd. for $6\left(\mathrm{C}_{20} \mathrm{H}_{32} \mathrm{CuN}_{2} \mathrm{O}_{18} \mathrm{~S}_{2}\right): \mathrm{C}, 33.54 \% ; \mathrm{H}, 4.50 \% ; \mathrm{N}$, $3.91 ; \mathrm{S}, 8.95 \%$; $\mathrm{Cu}, 8.87 \%$. Found: C, $33.50 \%$; $4.57 \%$; N, $3.93 \%$; S, $8.90 \%$; Cu, $8.89 \%$.

\subsection{Antimicrobial assay}

In this study, microorganisms of Staphylococcus aureus (ATCC 29213; Gram-positive), Escherichia coli (ATCC 25922; Gram-negative), Candida krusei (ATCC 6258; yeast) and Candida parapsilosis (ATCC 22019; yeast) were used. Microorganisms were obtained from Eskişehir Osmangazi University Faculty of Medicine.

\subsubsection{Determination of antimicrobial effect by microdilution method}

The minimum inhibitory concentrations (MICs) of the starting materials $\left(\mathrm{H}_{3} \mathrm{ssa}\right.$, Etpip,
HOEtpip and Acpip) and synthesized compounds 1-6 against bacterial strains (S. aureus and E. coli) and yeasts ( $C$. krusei and $C$. parapsilosis) were determined. The MICs of reference antibiotics levofloxacin, cefepime, vancomycin and flucanazole were compared with the newly synthesized compounds 1-6. For this purpose, U-shaped 96-well microplates were used in the microdilution method.

\subsubsection{Microdilution method}

MHB medium was prepared at single and double strength. The synthesized compounds (4 $\mathrm{mg}$ ) and antibiotics (4 mg) were dissolved in $2 \mathrm{ml}$ of DMSO. The bacteria and fungi used were incubated overnight in single-strength MHB medium and their cultures freshly prepared. Suspensions of the cultures were prepared and cell densities were adjusted to $0.5 \mathrm{McF}$ arland tube turbidity $\left(1.0 \times 10^{8}\right.$ $(\mathrm{kob}) / \mathrm{ml})$.

\section{RESULTS AND DISCUSSION}

The syntheses of proton transfer salts $\mathbf{1}$ and $\mathbf{2}$ obtained by the reactions of Etpip $\left(\mathrm{C}_{2} \mathrm{H}_{5}\right)$ and HOEtpip $\left(\mathrm{C}_{2} \mathrm{H}_{4} \mathrm{OH}\right)$ with $\mathrm{H}_{3}$ ssa are shown in Figure 1a. Treatment of Acpip $\left(\mathrm{COCH}_{3}\right)$ with $\mathrm{H}_{3}$ ssa yielded the proton transfer salt $\mathbf{3}$, as shown in Figure $1 \mathrm{~b}$.

The three metal complexes 4-6 were synthesized as a result of the reaction of the obtained proton transfer salts 1-3 with $\mathrm{Cu}(\mathrm{Ac})_{2} \cdot \mathrm{H}_{2} \mathrm{O}$. The proposed structures of $\mathrm{Cu}$ (II) complexes are shown in Figure 2. 
<smiles>[X]N1CCNCC1</smiles>

$\mathrm{H}_{3} \mathrm{ssa}$

$$
\mathrm{X}=\mathrm{C}_{2} \mathrm{H}_{5}(\mathbf{1}) ; \mathrm{X}=\mathrm{C}_{2} \mathrm{H}_{4} \mathrm{OH}(\mathbf{2})
$$

a<smiles>O=C(O)c1cc(S(=O)(=O)O)ccc1O</smiles><smiles>CC(=O)N1CCNCC1</smiles><smiles>CC(=O)N1CCNCC1</smiles>

Fig. 1. Syntheses of proton transfer salts 1-3. (a for $\mathbf{1}$ and $\mathbf{2}$, b for $\mathbf{3}$ )

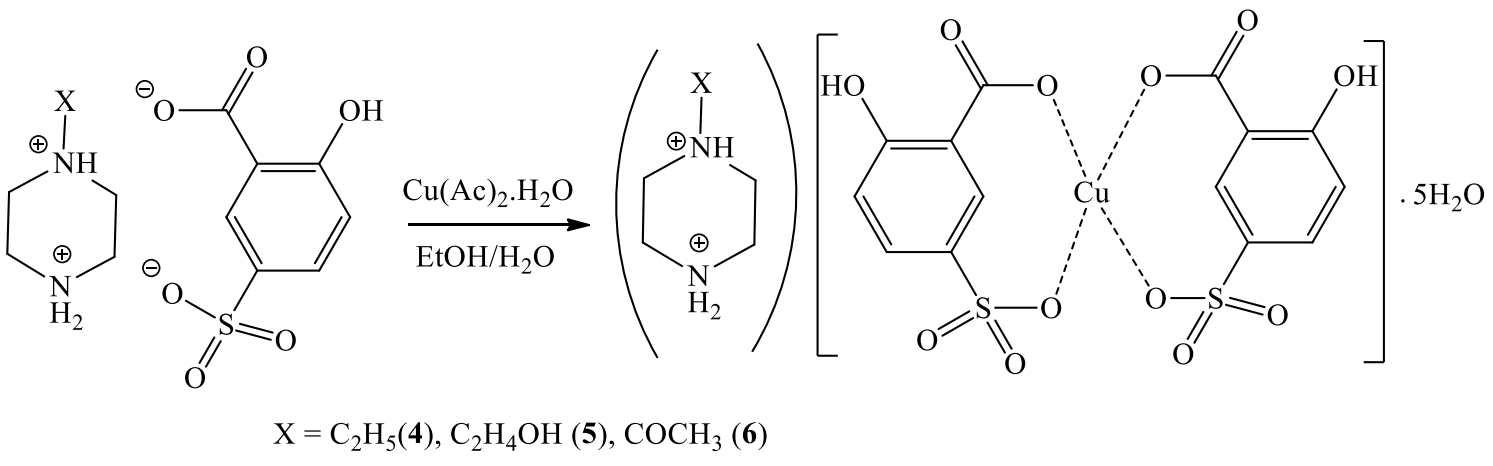

Fig. 2. Syntheses of metal complexes (4-6)

\subsection{NMR $\left({ }^{1} \mathrm{H}\right.$ and $\left.{ }^{13} \mathrm{C}\right)$ spectra \\ 3.1.1. NMR $\left({ }^{1} \mathrm{H}\right.$ and $\left.{ }^{13} \mathrm{C}\right)$ spectra of $\left(\mathrm{H}_{2}\right.$ Etpip $)(\mathrm{Hssa})(\mathbf{1})$}

The ${ }^{1} \mathrm{H}$ and ${ }^{13} \mathrm{C}$ NMR (DMSO- $\mathrm{d}_{6}, 25^{\circ} \mathrm{C}$ ) spectra of the synthesized proton transfer salt (1) are given in Figures S1 and S2, respectively, and the data of these spectra are given in Table 2. The signals in ${ }^{1} \mathrm{H}$ NMR spectrum of $\mathbf{1}$ are assigned as follows:

The two doublets for the protons $\mathrm{H}^{6}$ and $\mathrm{H}^{7}$ of $\mathrm{Hssa}^{2-}$ ring, both with $1 \mathrm{H}$ intensity, are observed at $7.58 \mathrm{ppm}\left(\mathrm{H}^{6},{ }^{3} \mathrm{~J}_{\mathrm{H} 6-\mathrm{H} 7}=7.43 \mathrm{~Hz}\right)$ and $6.77 \mathrm{ppm}$ $\left(\mathrm{H}^{7},{ }^{3} \mathrm{~J}_{\mathrm{H} 7 \mathrm{H} 6}=8.14 \mathrm{~Hz}\right)$, respectively. A singlet with $1 \mathrm{H}$ intensity is observed at $8.07 \mathrm{ppm}$ corresponding to proton $\mathrm{H}^{4}$. The two singlets, both with $4 \mathrm{H}$ intensity, at $3.29 \mathrm{ppm}\left(\mathrm{H}^{13}\right.$ and $\left.\mathrm{H}^{17}\right)$ and at
$3.07 \mathrm{ppm}\left(\mathrm{H}^{14}\right.$ and $\left.\mathrm{H}^{16}\right)$ arise from the piperazine ring $\left(\mathrm{H}_{2} \mathrm{Etpip}^{2+}\right)$ protons. The ethyl group protons of the piperazine ring are observed at $2.85 \mathrm{ppm}$ for the $\mathrm{H}^{18}$ proton and at $1.10 \mathrm{ppm}$ for the $\mathrm{H}^{19}$ proton, both as singlets. In salt formation, protons of $-\mathrm{COOH}\left(\mathrm{H}^{1}\right)$ and $-\mathrm{SO}_{3} \mathrm{H}\left(\mathrm{H}^{11}\right)$ are not observed in the ${ }^{1} \mathrm{H}$ NMR spectrum of $\mathbf{1}$ since they are transferred to the base (Etpip).

As expected, 11 carbon signals are observed in the ${ }^{13} \mathrm{C}$ NMR spectrum of $\mathbf{1}$. The peak at $173.035 \mathrm{ppm}$ is assigned to the carboxyl group carbon $\left(-\mathrm{C}^{2} \mathrm{OO}\right)$. The six signals in the range $109.988-$ $162.402 \mathrm{ppm}$ belong to aromatic carbon atoms $\left(\mathrm{C}^{3}\right.$ and $\left.\mathrm{C}^{8}\right)$. The carbon atoms of the piperazine ring are observed at $41.721\left(\mathrm{C}^{13}\right.$ and $\left.\mathrm{C}^{17}\right)$ and $48.327 \mathrm{ppm}$ $\left(\mathrm{C}^{14}\right.$ and $\left.\mathrm{C}^{16}\right)$ and the ethyl group $\mathrm{C}^{18}$ and $\mathrm{C}^{19}$ carbons attached to the piperazine group are observed at 51.423 and $10.225 \mathrm{ppm}$, respectively. 
Table 2

${ }^{1} \mathrm{H} N M R$ and ${ }^{13} \mathrm{C}$ NMR chemical shifts (ppm) with coupling constants $(\mathrm{Hz})$ and assignments for compound 1

\begin{tabular}{|c|c|c|c|}
\hline $\mathrm{H}^{1}$ & - & $\mathrm{C}^{2}$ & 173.035 \\
\hline $\mathrm{H}^{4}$ & $8.07(1 \mathrm{H}, \mathrm{s})$ & $\mathrm{C}^{3}$ & 109.988 \\
\hline $\mathrm{H}^{6}$ & $7.58(1 \mathrm{H}, \mathrm{d})\left({ }^{3} \mathrm{~J}_{\mathrm{H} 6-\mathrm{H} 7}=7.43 \mathrm{~Hz}\right)$ & $\mathrm{C}^{4}$ & 128.296 \\
\hline $\mathrm{H}^{7}$ & $6.77(1 \mathrm{H}, \mathrm{d})\left({ }^{3} \mathrm{~J}_{\mathrm{H} 7-\mathrm{H} 6}=8.14 \mathrm{~Hz}\right)$ & $\mathrm{C}^{5}$ & 137.785 \\
\hline $\mathrm{H}^{9}$ & $8.30(1 \mathrm{H}, \mathrm{s})$ & $\mathrm{C}^{6}$ & 131.395 \\
\hline $\mathrm{H}^{11}$ & - & $\mathrm{C}^{7}$ & 116.003 \\
\hline $\mathrm{H}^{12}$ & - & $\mathrm{C}^{8}$ & 162.402 \\
\hline $\mathrm{H}^{13}, \mathrm{H}^{17}$ & $3.29(4 \mathrm{H}, \mathrm{s})$ & $\mathrm{C}^{13}, \mathrm{C}^{17}$ & 41.721 \\
\hline $\mathrm{H}^{14}, \mathrm{H}^{16}$ & $3.07(4 \mathrm{H}, \mathrm{s})$ & $\mathrm{C}^{14}, \mathrm{C}^{16}$ & 48.327 \\
\hline $\mathrm{H}^{15}$ & - & $\mathrm{C}^{18}$ & 51.423 \\
\hline $\mathrm{H}^{18}$ & $2.85(2 \mathrm{H}, \mathrm{s})$ & $\mathrm{C}^{19}$ & 10.225 \\
\hline $\mathrm{H}^{19}$ & $1.10(3 \mathrm{H}, \mathrm{s})$ & & \\
\hline
\end{tabular}

\subsection{2. $N M R\left({ }^{1} H\right.$ and $\left.{ }^{13} C\right)$ spectra of $\left(\mathrm{H}_{2} \mathrm{HOEtpip}\right)(\mathrm{Hssa})(\mathbf{2})$}

The ${ }^{1} \mathrm{H}$ and ${ }^{13} \mathrm{C}$ NMR (DMSO- $\mathrm{d}_{6}, 25{ }^{\circ} \mathrm{C}$ ) spectra of the synthesized proton transfer salt 2 are given in Figures S3 and S4, respectively, and the data of these spectra are given in Table 3.
The ${ }^{1} \mathrm{H}$ NMR spectrum of 2 shows three signals for $\mathrm{Hssa}^{2}$ - ring protons in the aromatic region. Two doublets for protons $\mathrm{H}^{6}$ and $\mathrm{H}^{7}$, both with $1 \mathrm{H}$ intensity, are observed at $7.65 \mathrm{ppm}\left(\mathrm{H}^{6}\right.$, $\left.{ }^{3} \mathbf{J}_{\mathrm{H} 6-\mathrm{H} 7}=7.71 \mathrm{~Hz}\right)$ and $6.85 \mathrm{ppm}\left(\mathrm{H}^{7},{ }^{3} \mathbf{J}_{\mathrm{H} 7-\mathrm{H} 6}=\right.$ $7.93 \mathrm{~Hz})$, respectively. The third proton $\left(\mathrm{H}^{4}\right)$ signal of the $\mathrm{Hssa}^{2-}$ ring is observed as a singlet at $8.07 \mathrm{ppm}$ with $1 \mathrm{H}$ intensity.

T a ble 3

${ }^{1} \mathrm{H}$ and ${ }^{13} \mathrm{C}$ NMR chemical shifts (ppm) with coupling constants $(\mathrm{Hz})$ and assignments for compound 2

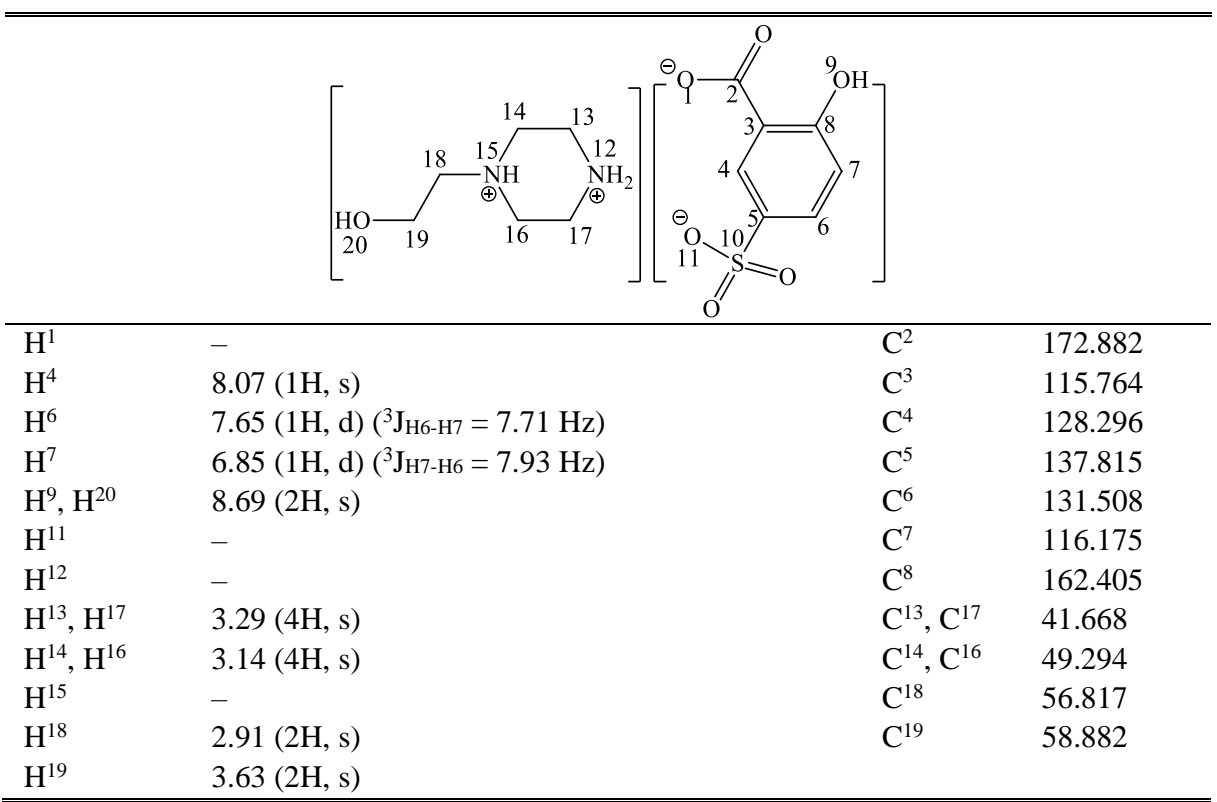


The two singlets for protons $\mathrm{H}^{13}-\mathrm{H}^{17}$ and $\mathrm{H}^{14}$ $\mathrm{H}^{16}$, each of $4 \mathrm{H}$ intensity, were observed at $3.29 \mathrm{ppm}$ and $3.14 \mathrm{ppm}$ respectively. The two singlets for protons $\mathrm{H}^{18}$ and $\mathrm{H}^{19}$, with $2 \mathrm{H}$ intensity each, are seen at $2.91 \mathrm{ppm}$ and $3.63 \mathrm{ppm}$, respectively. A singlet with intensity of $2 \mathrm{H}$ is observed at $8.69 \mathrm{ppm}$, corresponding to the protons $\mathrm{OH}\left(\mathrm{H}^{9}\right.$ and $\left.\mathrm{H}^{20}\right)$. The absence of $-\mathrm{COOH}\left(\mathrm{H}^{1}\right)$ and $-\mathrm{SO}_{3} \mathrm{H}\left(\mathrm{H}^{11}\right)$ protons in the NMR spectrum of $\mathbf{2}$ is evidence of salt formation. These protons are thought to be transferred to the $\mathrm{N}^{12}$ and $\mathrm{N}^{15}$ atoms of the piperazine ring.

The ${ }^{13} \mathrm{C}$ NMR spectrum of $\mathbf{2}$ is in good agreement with that expected. It exhibits 11 signals. The peak at $172.882 \mathrm{ppm}$ corresponds to the carboxyl group carbon $\left(-\mathrm{C}^{2} \mathrm{OO}\right)$. Six signals in the range of $162.405-15.764 \mathrm{ppm}$ belong to aromatic carbon atoms $\left(\mathrm{C}^{3}\right.$ and $\left.\mathrm{C}^{8}\right)$. The piperazine carbons $\mathrm{C}^{13}-\mathrm{C}^{17}$ and $\mathrm{C}^{14}-\mathrm{C}^{16}$, each with $2 \mathrm{C}$ intensity, are seen at 41.668 and 49.294 ppm, respectively. The carbon atoms in the ethyl group bound to the piperazine ring are observed at 56.817 for $\mathrm{C}^{18}$ and $58.882 \mathrm{ppm}$ for $\mathrm{C}^{19}$.

\subsubsection{NMR $\left({ }^{1} \mathrm{H}\right.$ and $\left.{ }^{13} \mathrm{C}\right)$ spectra of $(\mathrm{HAcpip})\left(\mathrm{H}_{2} \mathrm{Ssa}\right)(\mathbf{3})$}

The ${ }^{1} \mathrm{H}$ and ${ }^{13} \mathrm{C}$ NMR (DMSO- $\mathrm{d}_{6}, 25{ }^{\circ} \mathrm{C}$ ) spectra of the synthesized proton transfer salt (3) are given in Figures S5 and S6, respectively, and the data of these spectra are given in Table 4.

The proton of $-\mathrm{COOH}\left(\mathrm{H}^{1}\right)$ group is not observed in the ${ }^{1} \mathrm{H}$ NMR spectrum of 3 . This proton is thought to be transferred to the nitrogen
$\left(\mathrm{N}^{15}\right)$ atom of the piperazine ring in salt formation. Two broad singlets at $11.47 \mathrm{ppm}$ with $1 \mathrm{H}$ intensity and at $8.76 \mathrm{ppm}$ with $2 \mathrm{H}$ intensity correspond the protons $-\mathrm{SO}_{3} \mathrm{H}\left(\mathrm{H}^{11}\right)$ and $\mathrm{OH}+\mathrm{NH}\left(\mathrm{H}^{9}\right.$ and $\left.\mathrm{H}^{12}\right)$, respectively. The protons $-\mathrm{OH}\left(\mathrm{H}^{9}\right)$ and $-\mathrm{SO}_{3} \mathrm{H}\left(\mathrm{H}^{11}\right)$ have remain nonionized. The protons $\mathrm{H}^{6}$ and $\mathrm{H}^{7}$ of the $\mathrm{H}_{2}$ ssa ring, with intensity of $1 \mathrm{H}$ each, are observed as doublets at $7.71 \mathrm{ppm}\left({ }^{3} \mathrm{~J}_{\mathrm{H} 6-\mathrm{H} 7}\right.$ $=8.55 \mathrm{~Hz})$ and $6.91 \mathrm{ppm}\left({ }^{3} \mathrm{~J}_{\mathrm{H} 7-\mathrm{H} 6}=8.51 \mathrm{~Hz}\right)$, respectively. The singlet with $1 \mathrm{H}$ intensity at $8.05 \mathrm{ppm}$ corresponds to the proton $\mathrm{H}^{4}$. The signals observed as a triplet with $4 \mathrm{H}$ intensity for protons $\mathrm{H}^{13}-\mathrm{H}^{17} \quad\left({ }^{3} \mathrm{~J}_{\mathrm{H} 13 / \mathrm{H} 17-\mathrm{H} 14 / \mathrm{H} 16}=4.99 \mathrm{~Hz}\right)$ and a singlet+singlet with $4 \mathrm{H}$ intensity for protons $\mathrm{H}^{14}-\mathrm{H}^{16}$ are seen at $3.59 \mathrm{ppm}$ and at $3.10 \mathrm{ppm}$, respectively. The acetyl methyl group protons $\left(\mathrm{H}^{19}\right)$ are observed as a singlet at $1.99 \mathrm{ppm}$ with $3 \mathrm{H}$ intensity.

The ${ }^{13} \mathrm{C}$ NMR spectrum of $\mathbf{3}$ displays 11 resonances. The peak at $172.047 \mathrm{ppm}$ corresponds to carboxyl group carbon $\left(-\mathrm{C}^{2} \mathrm{OO}\right)$. The six resonances in the aromatic region in the range $161.772-112.258 \mathrm{ppm}$ belong to aromatic carbons $\left(\mathrm{C}^{3}\right.$ and $\left.\mathrm{C}^{8}\right)$. The signals at $38.031\left(\mathrm{C}^{13}\right.$ and $\left.\mathrm{C}^{17}\right)$ and 43.318 ppm $\left(\mathrm{C}^{14}\right.$ and $\left.\mathrm{C}^{16}\right)$ are from the piperazine ring carbons. The acetyl group carbons $\mathrm{C}^{18}$ and $\mathrm{C}^{19}$ attached to the piperazine ring are observed at 169.080 and $21.421 \mathrm{ppm}$, respectively.

The ratio of acid $\left(\mathrm{H}_{3} \mathrm{ssa}\right)$ to base (Etpip, HOEtpip, or Acpip) was found to be 1:1 from the ${ }^{1} \mathrm{H}$ and ${ }^{13} \mathrm{C}$ NMR spectra data of the prepared salts 1-3. These results are in good agreement with the structures proposed in Figure 1.

Ta ble 4

${ }^{1} \mathrm{H}$ and ${ }^{13} \mathrm{C}$ NMR chemical shifts (ppm) with coupling constants $(\mathrm{Hz})$ and assignments for compound 3

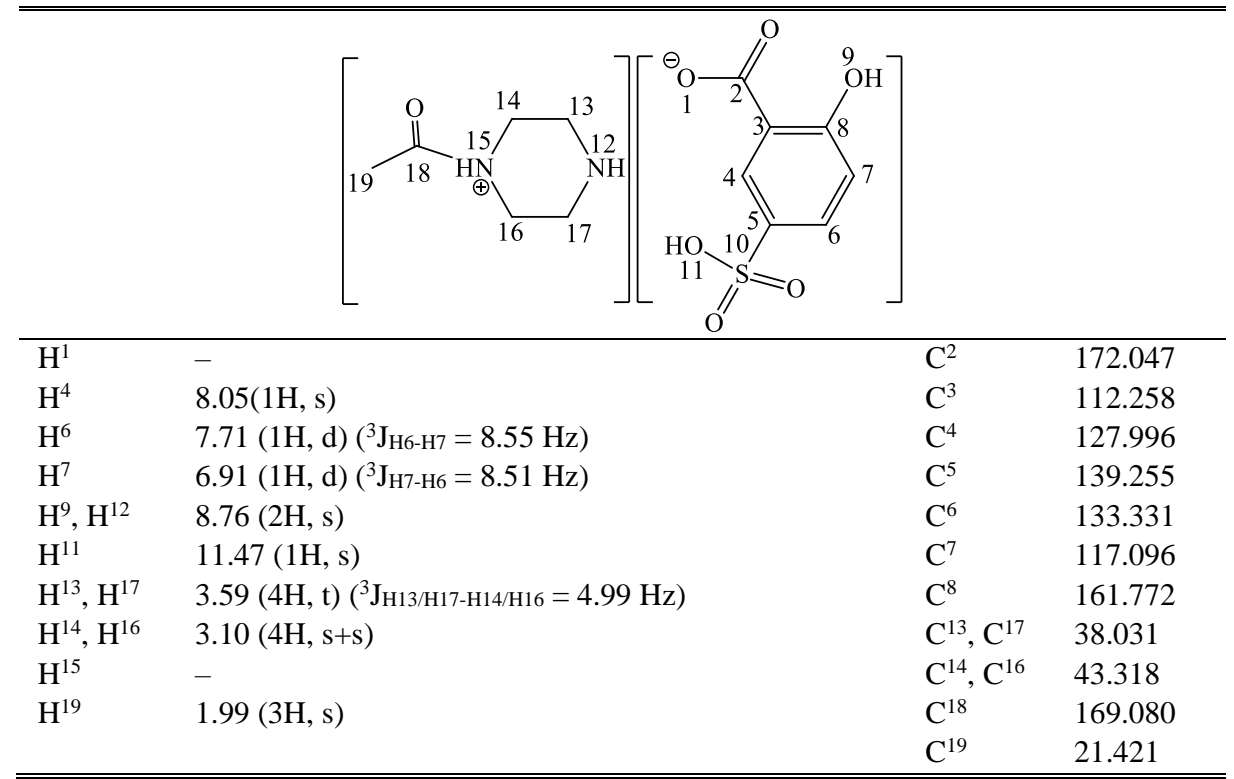




\subsection{FT-IR measurements}

The FT-IR spectra and data of the compounds 1-6 are given in Table 5 and Figures S7$\mathrm{S} 12$, respectively. The phenolic $-\mathrm{OH}$ vibration bands of compounds $\mathbf{1}$ and $\mathbf{2}$ are observed at 3448 and $3309 \mathrm{~cm}^{-1}$, respectively, while the $\mathrm{OH}$ vibration of the $-\mathrm{COOH}$ and $-\mathrm{SO}_{3} \mathrm{H}$ groups of 5sulfosalicylate are not observed. The FT-IR spectrum of proton transfer salt $\mathbf{3}$ shows a very broad absorption band in the range of $3000-2500 \mathrm{~cm}^{-1}$ attributed to the $v(\mathrm{O}-\mathrm{H})$ vibration of the $-\mathrm{SO}_{3} \mathrm{H}$ group. The broad bands at $3420 \mathrm{~cm}^{-1}$ for 4 , at $3372-3325 \mathrm{~cm}^{-1}$ for 5 and at $3449 \mathrm{~cm}^{-1}$ for $\mathbf{6}$ are attributed to the $v(\mathrm{OH})$ vibrations of uncoordinated $\mathrm{H}_{2} \mathrm{O}$ molecules and phenolic $\mathrm{OH}$ in complexes 4 6. The band due to $v(\mathrm{~N}-\mathrm{H})$ stretching vibration for 3 was observed at $3352 \mathrm{~cm}^{-1}$, but not for proton transfer salts $\mathbf{1}$ and $\mathbf{2}$ and also complexes 4-6, which confirms that only one nitrogen atom is protonated in compound 3 . In the high-frequency region, weak bands at $2978-2742 \mathrm{~cm}^{-1}$ and 3153 $3011 \mathrm{~cm}^{-1}$ are attributed to the stretching vibrations of aliphatic $v(\mathrm{C}-\mathrm{H})$ and aromatic $v(\mathrm{C}-\mathrm{H})$ vibrations for all compounds 1-6. For compounds containing the $-\mathrm{COOH}$ group, the $v(\mathrm{C}=\mathrm{O})$ stretching band is the most characteristic band in the FT-IR spectra and is expected to be in the range of 1660
$1700 \mathrm{~cm}^{-1}$ [37]. The absence of characteristic $v(\mathrm{C}=\mathrm{O})$ vibration band for the $-\mathrm{COOH}$ group in the FT-IR spectra of compounds 1-6 indicates that these groups are deprotonated [27]. The strong asymmetrical stretching and weak symmetrical vibration bands of carboxylate ions are observed at 1634 and $1423 \mathrm{~cm}^{-1}$ for $\mathbf{1}$, at 1617 and $1430 \mathrm{~cm}^{-1}$ for 2 , and at 1612 and $1432 \mathrm{~cm}^{-1}$ for 3 , respectively [38]. These bands confirm the proton transfer from the $-\mathrm{COOH}$ group of 5 -sulfosalicylic acid to the nitrogen atoms of the piperazine rings. These bands are observed at 1602 and $1423 \mathrm{~cm}^{-1}$ for 4 , at 1601 and $1440 \mathrm{~cm}^{-1}$ for 5 and at 1606 and $1431 \mathrm{~cm}^{-1}$ for $6[39,40]$. Also, the strong $v(\mathrm{C}=\mathrm{O})$ stretching vibration band is observed at 1680 and $1647 \mathrm{~cm}^{-1}$ for the acetyl group of the piperazine rings of $\mathbf{3}$ and $\mathbf{6}$, repectively. According to the literature [41], the differences between asymmetric and symmetric stretches of carboxylate groups higher than $200 \mathrm{~cm}^{-1}$ are monodentate. The $\Delta$-values are $179 \mathrm{~cm}^{-1}$ for $4,161 \mathrm{~cm}^{-1}$ for 5 and $180 \mathrm{~cm}^{-1}$ for $\mathbf{6}$, which suggests bidentate coordination of the carboxylate and sulfonyl group of 5-sulfosalicylate to the metal ion. The relatively weak and broad band in the range of $2717-2633 \mathrm{~cm}^{-1}$ is attributed to the $v\left(\mathrm{~N}^{+}-\mathrm{H}\right)$ vibration for both proton transfer salts $\mathbf{1}-$ 3 and complexes 4-6 [28].

Table 5

FT-IR spectral data $\left(\mathrm{cm}^{-1}\right)$ of proton transfer salts 1-3 and complexes 4-6

\begin{tabular}{|c|c|c|c|c|c|c|}
\hline & $\overline{11}$ & 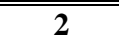 & 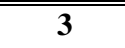 & 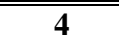 & 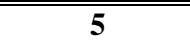 & 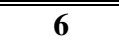 \\
\hline$v(\mathrm{O}-\mathrm{H})$ & 3448(b) & 3309(b) & $3000(b)$ & $3420(b)$ & $3372-3325(b)$ & 3449(b) \\
\hline$v(\mathrm{NH})$ & - & - & $3352(\mathrm{~m})$ & - & - & - \\
\hline$v(\mathrm{C}-\mathrm{H})_{\mathrm{ar}}$ & $3153(w)$ & $3125(w)$ & 3073(w) & 3011(w) & $3030(w)$ & $3026(w)$ \\
\hline \multirow[t]{3}{*}{$v(\mathrm{C}-\mathrm{H})_{\text {aliph.. }}$} & 2978(w) & $2956(w)$ & $2965(w)$ & 2914(w) & 2976(w) & $2956(w)$ \\
\hline & 2814(w) & 2884(w) & $2808(w)$ & 2861(w) & 2928(w) & $2809(w)$ \\
\hline & & $2745(w)$ & & 2742(w) & 2777(w) & 2751(w) \\
\hline \multirow[t]{2}{*}{$v\left(\mathrm{~N}^{+}-\mathrm{H}\right)$} & $2679(w)$ & 2717(w) & $2633(w)$ & 2699(w) & 2707(w) & 2643(w) \\
\hline & 2485(w) & 2504(w) & 2495(w) & 2484(w) & 2501(w) & 2477(w) \\
\hline$v(\mathrm{C}=\mathrm{O})_{\text {acetyl }}$ & - & - & $1680(s)$ & - & - & 1647(s) \\
\hline$v(\mathrm{C}=\mathrm{O})_{\mathrm{as}}$ & 1634(s) & 1617(s) & 1612(s) & $1602(s)$ & $1601(\mathrm{~s})$ & $1606(\mathrm{~s})$ \\
\hline$v(\mathrm{C}=\mathrm{O})_{\mathrm{sym}}$ & 1423(s) & $1430(s)$ & 1432(s) & 1423(s) & $1440(\mathrm{~s})$ & 1431(s) \\
\hline \multirow[t]{4}{*}{$v(\mathrm{C}=\mathrm{C})$} & $1588(\mathrm{~s})$ & 1591(s) & 1584(s) & $1566(\mathrm{~s})$ & $1565(\mathrm{~s})$ & $1558(\mathrm{~s})$ \\
\hline & 1572(s) & $1555(\mathrm{~s})$ & 1519(s) & $1530(\mathrm{~s})$ & $1558(\mathrm{~s})$ & $1525(\mathrm{~s})$ \\
\hline & 1479 (s) & $1476(\mathrm{~s})$ & 1471(s) & $1475(\mathrm{~s})$ & $1517(\mathrm{~s})$ & 1471(s) \\
\hline & 1456(s) & 1463(s) & & & $1477(\mathrm{~s})$ & \\
\hline \multirow[t]{3}{*}{$v(\mathrm{C}-\mathrm{O})$} & 1372(s) & 1382(s) & 1371(s) & 1322(s) & $1338(\mathrm{~s})$ & $1390(\mathrm{~s})$ \\
\hline & $1238(\mathrm{~s})$ & $1258(\mathrm{~s})$ & 1233(s) & 1201(s) & $1203(\mathrm{~s})$ & $1250(\mathrm{~s})$ \\
\hline & 1076(s) & 1078(s) & $1078(\mathrm{~s})$ & 1086(s) & $1085(\mathrm{~s})$ & 1086(s) \\
\hline $\operatorname{vas}(\mathrm{S}=\mathrm{O})$ & 1264(s) & 1299(s) & 1289(s) & 1222(s) & $1271(\mathrm{~s})$ & 1271(s) \\
\hline$v_{\text {sym }}(S=O)$ & 1164(s) & $1150(\mathrm{~s})$ & 1141(s) & $1138(\mathrm{~s})$ & $1150(\mathrm{~s})$ & 1159 (s) \\
\hline$v(\mathrm{Cu}-\mathrm{O})$ & - & - & - & $609(w)$ & $606(w)$ & $607(w)$ \\
\hline
\end{tabular}

(b: broad, s: sharp, m: medium, w: weak) 
The aromatic $v(\mathrm{C}=\mathrm{C})$ stretching vibrations are seen in the of range 1591-1456 and $1566-1471 \mathrm{~cm}^{-1}$ for salts 1-3 and metal complexes 4-6, respectively. The $\mathrm{SO}_{2}$ asymmetric vibration for sodium 5sulphosalicylate dihydrate [5], is reported at $1300 \mathrm{~cm}^{-1}$. The FT-IR spectra of compounds show characteristic $v_{\text {as }}(\mathrm{S}=\mathrm{O})$ and $v_{\mathrm{sym}}(\mathrm{S}=\mathrm{O})$ vibration bands at 1264 and $1164 \mathrm{~cm}^{-1}$ for $\mathbf{1}$, at 1299 and $1150 \mathrm{~cm}^{-1}$ for 2 , at 1289 and $1141 \mathrm{~cm}^{-1}$ for 3, at 1222 and $1138 \mathrm{~cm}^{-1}$ for $\mathbf{4}$, at 1271 and $1150 \mathrm{~cm}^{-1}$ for 5 and at 1271 and $1159 \mathrm{~cm}^{-1}$ for $\mathbf{6}$, respectively $[42,43]$. The shift of these absorptions to lower frequency indicates salt formation for 1-3 and coordination with copper for 4-6 [43]. The $\mathrm{Cu}-\mathrm{O}$ vibration bands for metal complexes 4, 5 and $\mathbf{6}$ are observed at 609, 606 and $607 \mathrm{~cm}^{-1}$, respectively [44]. All these FT-IR data suggest the proposed structures of proton transfer salts 1-3 and coordination complexes 4-6, as shown in Figures 1 and 2, respectively.

\subsection{Magnetic susceptibility and molar conductivity of metal complexes 4-6}

The experimental and theoretical magnetic susceptibility and molar conductivity results of the synthesized metal complexes 4-6 are given in Table 6 . It is seen that the experimentally obtained values are consistent with the theoretical values and support the structures proposed in Figure 2. Magnetic susceptibilities of metal complexes 4-6 were found experimentally as $1.67,1.61$ and 1.65 $\mathrm{BM}$, respectively. These magnetic moment values of the $\mathrm{Cu}$ (II) complexes (4-6) indicate the presence of one unpaired electron $\left(\mathrm{d}^{9}\right)$ [45].

The molar conductivity data in DMSO are 50.20 for $\mathbf{4}, 48.80$ for 5 and $45.10 \Omega^{-1} \mathrm{~cm}^{2} \mathrm{~mol}^{-1}$ for $\mathbf{6}$, indicating that all complexes are ionic [46].

\section{Table 6}

\section{Magnetic susceptibility of metal complexes 4-6}

\begin{tabular}{cccccc}
\hline \hline Complexes & MExperimantally & M $_{\text {Theoretical }}$ & $\mathbf{n}$ & $\mathbf{d}^{\mathbf{x}}$ & $\mathbf{\Omega}$ \\
\hline $\mathbf{4}$ & 1.67 & 1.73 & 1 & $\mathrm{~d}^{9}$ & 50.20 \\
$\mathbf{5}$ & 1.61 & 1.73 & 1 & $\mathrm{~d}^{9}$ & 48.80 \\
$\mathbf{6}$ & 1.65 & 1.73 & 1 & $\mathrm{~d}^{9}$ & 45.10 \\
\hline \hline
\end{tabular}

*(BM: Bohr magneton, $\mathrm{n}$ : number of unpaired electrons)

\subsection{Atomic absorption spectra of metal complexes 4-6}

The AAS data of of the metal complexes 4 6 are given in Table 1. According to the AAS results, the metal/acid/base ratio in the synthesized metal complexes 4-6 is 1:2:1. These results are in good agreement with the proposed structures for the metal complexes 4-6 (Fig. 2).

Single X-ray diffraction studies could not be applied to identify the structures of complexes 4-6 due to their powder forms. Using elemental analysis, the formulas of the complexes were proposed with the help of FT-IR spectra and magnetic susceptibility and molar conductivity studies (Fig. 2).

\subsection{Antimicrobial activity results}

In this study, the antibacterial and antifungal activities of the starting materials $\left(\mathrm{H}_{3} \mathrm{ssa}\right.$, Etpip, HOEtpip, Acpip) and synthesized compounds 1-6 were measured by a microdilution method. The MIC values of the synthesized compounds 1-6 are given in Table 7. When the results were evaluated, it was observed that most of the compounds showed antibacterial and antifungal properties, but the antibacterial activities were more pronounced than the antifungal activities. The antimicrobial activity results obtained are in agreement with similar studies in the literature [47-49]. Most of the compounds were found to be effective against $S$. aureus (Grampositive) and E. coli (Gram-negative) bacteria. In terms of antifungal activity, the compounds were shown to be more effective against the $C$. parapsilosis yeast strain than the $C$. krusei yeast.

The MIC values of the synthesized compounds against $S$. aureus were compared with vancomycin as control compound, when it was observed that the complexes 4-6 are more effective than vancomycin, and the proton transfer salt $\mathbf{1}$ has similar activity to that of vancomycin. The other compounds were observed to have lower activity. Proton transfer salt $\mathbf{1}(31.25 \mu \mathrm{g} / \mathrm{ml})$ and synthesized complexes 4-6 $(15.60 \mu \mathrm{g} / \mathrm{ml})$ showed better activity against $S$. aureus than the control compounds levofloxacin and cefepime (62.50), while free ligands $\left(\mathrm{H}_{3} \mathrm{ssa}\right.$, Etpip, HOEtpip and Acpip) and proton transfer salts $\mathbf{2}$ and $\mathbf{3}$ were determined to have similar activity to those of levofloxacin and cefepime. Complexes $\mathbf{4}$ and $\mathbf{5}$ had similar activity to that of levofloxacin $(31.25 \mu \mathrm{g} / \mathrm{ml})$, while other compounds $(62.50-500.0 \mu \mathrm{g} / \mathrm{ml})$ were found to have less effect on the bacterial growth of E. coli $(31.25 \mu \mathrm{g} / \mathrm{ml})$ culture than did levofloxacin. Complexes 4 and 5 showed better activity than the control antibiotics vancomycin $(62.50 \mu \mathrm{g} / \mathrm{ml})$ and cefepime $(62.50 \mu \mathrm{g} / \mathrm{ml})$, while complex 6 showed similar activity to those of vancomycin and cefepime. 
Table 7

MIC values of the compounds $(\mu \mathrm{g} / \mathrm{ml})$

\begin{tabular}{|c|c|c|c|c|}
\hline Compound & S. aureus & E. coli & C. krusei & C.parapisilosis \\
\hline Vancomycin & 31.25 & 62.50 & - & - \\
\hline Levofloxacin & 62.50 & 31.25 & - & - \\
\hline Cefepime & 62.50 & 62.50 & - & - \\
\hline Fluconazole & - & - & - & 62.50 \\
\hline $\mathrm{H}_{3} \mathrm{ssa}$ & 62.50 & 250.00 & 62.50 & 31.25 \\
\hline Etpip & 62.50 & 125.00 & 125.00 & 31.25 \\
\hline HOEtpip & 62.50 & 500.00 & 250.00 & 31.25 \\
\hline Acpip & 62.50 & 125.00 & 31.25 & 31.25 \\
\hline 1 & 31.25 & 500.00 & 62.50 & 31.25 \\
\hline 2 & 62.50 & 125.00 & 62.50 & 31.25 \\
\hline 3 & 62.50 & 125.00 & 62.50 & 31.25 \\
\hline 4 & 15.60 & 31.25 & 15.60 & 15.60 \\
\hline 5 & 15.60 & 31.25 & 31.25 & 62.50 \\
\hline 6 & 15.60 & 62.50 & 15.60 & 15.60 \\
\hline
\end{tabular}

The starting compounds $\left(\mathrm{H}_{3} \mathrm{ssa}\right.$, Etpip, HOEtpip, and Acpip), proton transfer salts $\mathbf{1}-\mathbf{3}$ and metal complexes 4-6 were observed to have antifungal activity against $C$. krusei, while the control compound fluconazole showed no activity. Complexes 4 and 6 with MIC values of $15.60 \mu \mathrm{g} / \mathrm{ml}$ were found to have the highest activity of all the compounds. Newly synthesized complexes $\mathbf{4}$ and $\mathbf{6}$ $(15.60 \mu \mathrm{g} / \mathrm{ml})$ showed higher antimicrobial effect against $C$. parapsilosis compared to the control antibiotic fluconazole $(62.50 \mu \mathrm{g} / \mathrm{ml})$, proton transfer salts $\mathbf{1}-\mathbf{3}$ and free ligands $(31.25 \mu \mathrm{g} / \mathrm{ml})$.

\section{CONCLUSIONS}

In the present work, three new proton transfer salts $\left(\mathrm{H}_{2}\right.$ Etpip)(Hssa) (1), ( $\left.\mathrm{H}_{2} \mathrm{HOEtpip}\right)(\mathrm{Hssa})$ (2), (HAcpip) $\left(\mathrm{H}_{2} \mathrm{ssa}\right)(3)$ and their $\mathrm{Cu}$ (II) complexes 4-6 were synthesized. All measurements showed good agreement with the proposed structures of metal complexes 4-6. Antimicrobial activities of all new compounds 1-6 were tested against S. aureus (Gram-positive), E. coli (Gram-negative), C. krusei (yeast) and C. parapsilosis (yeast). When the results of antibacterial and antifungal tests of the synthesized compounds 1-6 were compared with the control antimicrobial compounds (vancomycin, levofloxacin, cefepime and fluconazole), complexes 4-6 showed higher activity against yeasts (C. krusei and C. parapsilosis) than against bacteria (S. aureus and E. coli).

Acknowledgment. This work was supported by Dumlupınar University Research Foundation (Grant No:
2015-59) and was carried out at the Chemistry Department of the same university.

\section{REFERENCES}

[1] O. M. Yaghi, C. E. Davis, G. Li, H. Li. Selective guest binding by tailored channels in a 3 -D porous zinc (II) benzene tricarboxylate network. J. Am. Chem. Soc. 119 , 2861-2868 (1997). DOI: 10.1021/ja9639473.

[2] C. Swiegers, T. Malefetse, New self-assembled structural motifs in coordination chemistry. Chem. Rev. 100, 3483-3538 (2000). DOI: 10.1021/cr990110s.

[3] A. Cote, G. K. H. Shimizu, The supramolecular chemistry of the sulfonate group in extended solids. Coor. Chem. Rev. 245, 49-64 (2003).

DOI: $10.1016 / \mathrm{S} 0010-8545(03) 00033-\mathrm{X}$.

[4] J.F. Song, Y. Chen, Z.G. Li, R.S. Zhou, X.Y. Xu, J. Q. $\mathrm{Xu}$, T.G. Wang, Syntheses, supramolecular structures and properties of six coordination complexes based on 5 -sulfosalicylic acid and bipyridyl-like chelates. Polyhedron 26, 4397-4410 (2007). DOI: $10.1016 /$ j.poly.2007.05.037.

[5] A. Marzotto, D. A. Clemente, T. Gerola, G. Valle, Synthesis, molecular structure and reactivity of sodium 5sulfosalicylate dihydrate and sodium [triaqua (5sulfosalicylato) copper (II)] 2 hemihydrate. Polyhedron 20, 1079-1087 (2001). DOI: 10.1016/S0277-5387(01)00765-3.

[6] Z. G. Aliev, L. O. Atovmyan, Crystal structure of sodium sulfosalicylate dihydrate $\mathrm{NaC}_{7} \mathrm{H}_{5} \mathrm{O}_{6} \mathrm{~S} \cdot 2 \mathrm{H}_{2} \mathrm{O}$. J. Struct. Chem. 42, 506-508 (2001).

[7] Y. Li, L. Deng, X. Zhou, S. Zhang, Q. Yang, The crystal structure and the second harmonic generation efficiency of the sulfosalicylate. Acta Phys.-Chim. Sin. 14, 778783 (1998). DOI: 10.3866/PKU.WHXB19980903.

[8] M. Hu, C. Geng, S. Li, Y. Du, Y. Jiang, L. Zhihong, Syntheses and crystal structures of three cesium salts: 
cesium 5-sulfosalicylate, cesium 3,5-dinitrosalicylate and cesium 2, 4-dinitrophenoxide monohydrate. J. Organomet. Chem. 690, 3118-3124 (2005).

DOI: 10.1016/j.jorganchem.2005.04.001.

[9] S. Gao, L. H. Huo, Z. B. Zhu, J. R. Li, CatenaPoly[[[tetraaqua (3-carboxy-4-hydroxy-benzenesulfonato) strontium (II)]- $\mu^{3}-3$-carboxy-4-hydroxybenzenesulfonato] dihydrate]. Acta Cryst. E61, m417-m419 (2005). DOI: $10.1107 / \mathrm{S} 1600536805002801$.

[10] J. F. Ma, J. Yang, L. Li, G. L. Zheng, J. F. Liu, The first ladder structure containing three different squares: the structure of barium 3-carboxy-4-hydroxybenzenesulfonate. Inorg. Chem. Commun. 6, 581-583 (2003). DOI: 10.1016/S1387-7003(03)00044-3.

[11] Z. G. Aliev, L. O. Atovmyan, T. A. Baranova, S. B. Pirkes, Crystalline-structure of $\mathrm{La}\left(\mathrm{C}_{6} \mathrm{H}_{3} \mathrm{OHCOOHSO}_{3}\right)_{3} .9 \mathrm{H}_{2} \mathrm{O}$ lanthanum, Russ. J. Coor. Chem. 17, 1282 (1991).

[12] A. Rohde, W. Urland, Octaaquaytterbium(III) tris(3carboxy-4-hydroxy-benzenesulfonate) monohydrate. Acta Cryst. E62, m1210-m1212 (2006). DOI: $10.1107 /$ S1600536806015583.

[13] Z. G. Aliev, T. A. Baranova, L. O. Atovmyan, S. B. Pirkes, Synthesis, structure and properties of samarium sulfosalicilate $\mathrm{SmH}\left(\mathrm{C}_{6} \mathrm{H}_{3} \mathrm{OHCOOSO}_{3}\right)_{2} \cdot 6 \mathrm{H} 2 \mathrm{O}$. Russ. $J$. Coor. Chem. 20, 150-152 (1994).

[14] X. Q. Wang, J. Zhang, Z. J. Li, Y. H. Wen, J. K. Cheng, Y. G. Yao, Poly[aquaneodymium(III)- $\mu^{5}-2$-oxido-5sulfonatobenzoato]. Acta Cryst. C60, 657-658 (2004). DOI: $10.1107 / \mathrm{S} 0108270104022280$.

[15] H. Y. Sun, C. H. Huang, X. H. Jin, G. X. Xu, The synthesis, crystal structure and synergistic fluorescence effect of a heteronuclear lanthanide complex (HLC) $\left\{\mathrm{Na}_{3} \mathrm{TbLa}_{2}\left(\mathrm{C}_{7} \mathrm{H}_{3} \mathrm{SO}_{6}\right)_{4} \cdot 26 \mathrm{H}_{2} \mathrm{O}\right\}$ n. Polyhedron 14, 1201-1206 (1995). DOI: $10.1016 / 0277-5387(94) 00378-R$

[16] H. Y. Sun, C. H. Huang, L. B. Gan, G. X. Xu, Z. S. Ma, N. C. Shi, The synthesis and crystal structure of heteronuclear complex of lanthanide with sulfo-salicylic acid $\left[\mathrm{Na}_{3} \mathrm{YLa}_{2}\left(\mathrm{C}_{7} \mathrm{H}_{3} \mathrm{SO}_{6}\right)_{4} \cdot 26 \mathrm{H}_{2} \mathrm{O}\right]_{n}$. Chin. J. Chem. 13, 150155 (1995). DOI: 10.1002/cjoc.19950130209.

[17] S. R. Fan, L. G. Zhu, H. P. Xiao, S. W. Ng, cis-Diaquabis (1,10-phenanthroline) manganese (II) 3-carboxylato-4hydroxybenzenesulfonate tetrahydrate, Acta Cryst. E61, m563-m565 (2005).

DOI: 10.1107/S1600536805004927/ww6357Isup2.hk1.

[18] W. G. Wang, J. Zhang, L. J. Song, J. F. Ju, Ferromagnetic linear trinuclear copper(II) complex bridged by sulfosalicylate ligand. Inorg. Chem. Commun. 7, 858-860 (2004). DOI: 10.1016/j.inoche.2004.05.006.

[19] S. R. Fan, L. G. Zhu, Influence of the reaction conditions on the self-assembly of lead(II) 5-sulfosalicylate coordination polymers with chelating amine ligands. Inorg. Chem. 45, 7935-7942 (2006). DOI: $10.1021 / \mathrm{ic} 060871 \mathrm{v}$.

[20] P. Starynowicz, Synthesis and crystal structure of europium(II) dihydrogen bis(sulfosalicylate) pentahydrate $\left[\mathrm{Eu}\left(\mathrm{C}_{7} \mathrm{H}_{5} \mathrm{O}_{6} \mathrm{~S}\right)_{2}\left(\mathrm{H}_{2} \mathrm{O}\right)_{5}\right]_{\infty}$. J. Alloys Comp. 305, 117-120 (2000). DOI: 10.1016/S0925-8388(00)00749-0.

[21] P. V. Khadikar, S. Joshi, S. G. Kashkhedikar, B. D. Heda, Metal-complexes of 5-sulfosalicylic acid and their antimicrobial activity. Indian J. Pharm. Sci. 46, 209-215 (1984).

[22] P. V. Khadikar, S. M. Ali, B. Pol, B. D. Heda, Effect of metal ions on the antimicrobial activity of 5sulphosalicylic acid. Acta Microbio. Immun. Hung. 33, 97-102 (1986).

[23] C. Yenikaya, N. Büyükkıdan, M. Sarı, R. Keşli, H. İlkimen, O. Büyükgüngör, Synthesis, characterization, and biological evaluation of $\mathrm{Cu}(\mathrm{II})$ complexes with the proton transfer salt of 2,6-pyridinedicarboxylic acid and 2amino-4-methylpyridine. J. Coord. Chem. 64, 33533365 (2011).

[24] M. Agotegaray, F. Gumilar, M. Boeris, R. Toso, A. Minetti, Enhanced analgesic properties and reduced ulcerogenic effect of a mononuclear copper(II) complex with fenoprofen in comparison to the parent drug: Promising insights in the treatment of chronic inflammatory diseases. BioMed. Res. Inter. 2014, 1-9 (2014). DOI: $10.1155 / 2014 / 505987$.

[25] H. İlkimen, C. Yenikaya, A. Gülbandılar, M. Sarı, Synthesis and characterization of a novel proton salt of 2amino-6-nitrobenzothiazole with 2,6-pyridinedicarboxylic acid and its metal complexes and their antimicrobial and antifungal activity studies. J. Mol. Struct. 1120, 25-33 (2016). DOI: 10.1016/j.molstruc.2016.04.068.

[26] E. Soleimani, Synthesis, characterization and antimicrobial activity of a novel macrocyclic ligand derived from the reaction of 2,6-pyridinedicarboxylic acid with homopiperazine and its $\mathrm{Co}(\mathrm{II}), \mathrm{Ni}(\mathrm{II}), \mathrm{Cu}(\mathrm{II})$, and $\mathrm{Zn}$ (II) complexes. J. Mol. Struct. 995, 1-8 (2011). DOI: 10.1016/j.molstruc.2011.01.002.

[27] S. R. Fan, L. G. Zhu, Structural diversity and fluorescent properties of copper(II) complexes constructed by 5sulfosalicylate and 2,2'-bipyridine. J. Mol. Struct. 827, 188-194 (2007). DOI: 10.1016/j.molstruc.2006.05.019.

[28] H. İlkimen, Y. Tekșen, C. Yenikaya, İ. Turhan, T. Tunç. M. Sarı, Synthesis, characterization and pharmacological evaluation of the proton transfer salts of 2aminobenzothiazole derivatives with 5-sulfosalicylic acid and their $\mathrm{Cu}(\mathrm{II})$ complexes. J. Coord. Chem. 71, 2831-2842 (2018).

DOI: 10.1080/00958972.2018.1504035.

[29] M. Ghadermazi, J. Soleimannejad, S. Sheshmani, M. Shamsipur, M. Ghanbari, M. R. Eslami, Characterization, crystal structures and solution studies of $\mathrm{Zn}(\mathrm{II})$, $\mathrm{Cd}(\mathrm{II})$ and $\mathrm{Mg}$ (II) complexes obtained from a proton transfer compound including pyridine-2-carboxylic acid and piperazine. J. Iran. Chem. Soc. 9, 579-589 (2012). DOI: 10.1007/s13738-012-0071-x.

[30] H. Aghabozorg, S. Daneshvar, E. Motyeian, F. Manteghi, R. Khadivi, M. Ghadermazi, A. Shokrollahi, M. Ghaedi, S. Derki, M. Shamsipur, Synthesis and crystal structure of $\mathrm{Mn}$ (II) and $\mathrm{Hg}$ (II) compounds and solution studies of $\mathrm{Mn}(\mathrm{II}), \mathrm{Zn}$ (II), $\mathrm{Cd}(\mathrm{II})$ and $\mathrm{Hg}$ (II) compounds based on piperazinedium pyridine-2,3-dicarboxylate. $J$. Iran. Chem. Soc. 6, 620-637 (2009).

[31] H. Aghabozorg, F. Manteghi, S. Sheshmani, A brief review on structural concepts of novel supramolecular proton transfer compounds and their metal complexes. $J$. Iran. Chem. Soc. 5,184-227 (2008).

[32] N. Büyükkıdan, C. Yenikaya, H. İlkimen, C. Karahan, C. Darcan, E. Şahin, Synthesis, characterization and an- 
timicrobial activity of a novel proton salt and its $\mathrm{Cu}(\mathrm{II})$ complex. Russian J. Coord. Chem. 39, 96-103 (2013). DOI: $10.1134 / \mathrm{S} 1070328412100028$

[33] K. Singh, H. H. Siddiqui, P. Shakya, P. Bagga, A. Kumar, M. Khalid, M. Arif, S. Alok, Piperazine - a biologically active scaffold. Inter. J. Pharm. Sci. Res. 6, 4145-58 (2015). DOI: 10.13040/IJPSR.0975-8232.6(10).4145-58.

[34] W. CunicoI, C. R. B. GomesI, W. T. A. Harrison, M. Moreth, J. L. Wardell, S. M. S. V. WardellI, Structure of (2R,3S)-4-(aryl methyl)-1-(4-phenyl-3-amino-2-hydroxy butyl) piperazine, potential anti malarial agents. Z. Kristallogr. 224, 461-470 (2009). DOI: $10.1524 /$ zkri.2009.1161

[35] M. Kimura, T. Masuda, K. Yamada, N. Kawakatsu, Antioxidative activities of novel diphenylalkyl piperazine derivatives with high affinities for the dopamine transporter. Bioorg. Med. Chem. Let. 14, 4287-4290 (2004). DOI: 10.1016/j.bmcl.2004.05.091.

[36] V. Cecchetti, F. Schiaffella, 1,4-Benzothiazinyloxy alkylpiperazine derivatives as potential antihypertensive agents. Bioorg. Med. Chem. Let. 10, 465-468 (2000). DOI: 10.1016/S0960-894X(00)00016-0.

[37] H. T. Varghese, C. Y. Panicker, D. Philip, IR, Raman and SERS spectra of 5-sulphosalicylic acid dihydrate. $J$. Raman Spect. 38, 309-315 (2007). DOI: $10.1002 /$ jrs. 1644 .

[38] R. Bhuvaneswari, K. S. Murugesan, Synthesis, growth, structural, dielectric, thermal, linear and nonlinear properties of 8-hydroxyquinolinium 3-carboxy-4-hydroxy benzene sulfonate monohydrate single crystal. Opt. Mat. 98, 109431 (2019). DOI: 10.1016/j.optmat.2019.109431.

[39] H. Aghabozorg, F. Mahfoozi, M. A. Sharif, A. Shokrollahi, S. Derkid, M. Shamsipur, H. R. Khavasi, A proton transfer self-associated compound from benzene1,2,4,5-tetracarboxylic acid and piperazine and its cobalt(II) complex: Syntheses, crystal structures and solution studies. J. Iran. Chem. Soc. 7, 727-739 (2010).

[40] H. Aghabozorg, F. Manteghi, M. Ghadermazi, M. Mirzaei, A. R. Salimi, H. Eshtiagh-Hosseini, Synthesis, Xray characterization and molecular structure of a novel supramolecular compound of antimony(III): Theoretical investigation on molecular and electronic properties based on the ab initio HF and various DFT methods. $J$. Iran. Chem. Soc. 7, 500-509 (2010).

[41] M. S. Nothenberg, A. R. Souza, J. R. Matos, Synthesis and physicochemical characterization of rhodium sulfosalicylate. Polyhedron 19, 1305-1309 (2000). DOI: 10.1016/S0277-5387(00)00394-6.

[42] M. S. Gruzdev, L. E. Shmukler, N. O. Kudryakova, A. M. Kolker, Y. A. Sergeeva, L. P. Safonova, Triethanolamine-based protic ionic liquids with various sulfonic acids: Synthesis and properties. J. Mol. Liq. 242, 838844 (2017). DOI: 10.1016/j.molliq.2017.07.078.

[43] Y. Zhang, J. R. Price, I. Karatchevtseva, Y. K. L. Bongho, F Kadi, R. 1. Gregory, L. Feng, Comparison of uranium(VI) and thorium(IV) coordination polymers with p-toluenesulfonic acid. Polyhedron 91, 98-103 (2015). DOI: 10.1016/j.poly.2015.03.002.

[44] A. Golcu, M. Tumer, H. Demirelli, R. A. Wheatley, $\mathrm{Cd}$ (II) and $\mathrm{Cu}$ (II) complexes of polydentate Schiff base ligands: synthesis, characterization, properties and biological activity. Inorg. Chim. Acta 358, 1785-1797 (2005). DOI: 10.1016/j.ica.2004.11.026.1785.

[45] H. İlkimen, N. Türken, A. Gülbandılar. Synthesis, characterization, antimicrobial and antifungal activity studies of two novel aminopyridine-sulfamoylbenzoic acid salts and their $\mathrm{Cu}(\mathrm{II})$ complexes. J. Iran. Chem. Soc. 18, 1941-1946 (2021). DOI: 10.1007/s13738-021-02157-4.

[46] W. J. Geary, The use of conductivity measurements in organic solvents for the characterisation of coordination compounds. Coor. Chem. Rev. 7, 81-122 (1971). DOI: 10.1016/S0010-8545(00)80009-0.

[47] P. V. Khadikar, S. Joshi, S. G. Kashkhedikar, B. D. Heda, Metal-complexes of 5-sulfosalicylic acid and their antimicrobial activity. Indian J. Pharm. Sci. 46, 209-211 (1984).

[48] B. D. Heda, P. V. Khadikar, S. G. Kaskedikar, Antifungal and antibacterial activities of cobalt II chelates of salicylic and substituted salicylic acids. Indian J. Pharm. Sci. 42, 174-175 (1980).

[49] G. D. Bajju, G. Devi, S. Katoch, M. Bhagat, D. Ashu, S. Kundan, A. K. Sunil, Synthesis, spectroscopic and biological studies on new zirconium(IV) porphyrins with axial ligand. Bioinorg. Chem. Appl. 903616, (2013). DOI: $10.1155 / 2013 / 903616$ 